BNL 857 (I-341)

320

$10 / 2 / 4$ BROOKHAVEN LECTURE SERIES

\title{
The Impact of Isotopic Tracers on Physiological Concepts
}

\author{
JAMES S. ROBERTSON
}

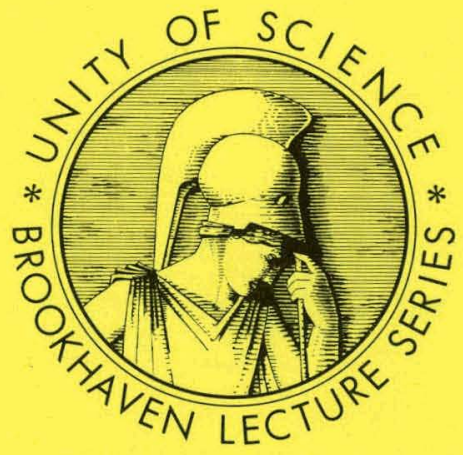

Number 33

February 12, 1964

BROOKHAVEN NATIONAL LABORATORY

Associated Universities, Inc.

under contract with the

United States Atomic Energy Commission 


\section{DISCLAIMER}

This report was prepared as an account of work sponsored by an agency of the United States Government. Neither the United States Government nor any agency Thereof, nor any of their employees, makes any warranty, express or implied, or assumes any legal liability or responsibility for the accuracy, completeness, or usefulness of any information, apparatus, product, or process disclosed, or represents that its use would not infringe privately owned rights. Reference herein to any specific commercial product, process, or service by trade name, trademark, manufacturer, or otherwise does not necessarily constitute or imply its endorsement, recommendation, or favoring by the United States Government or any agency thereof. The views and opinions of authors expressed herein do not necessarily state or reflect those of the United States Government or any agency thereof. 


\section{DISCLAIMER}

Portions of this document may be illegible in electronic image products. Images are produced from the best available original document. 


\section{FOREWORD}

The Brookhaven Lectures, held by and for the Brookhaven staff, are meant to provide an intellectual meeting ground for all scientists of the Laboratory. In this role they serve a double purpose: they are to acquaint the listeners with new developments and ideas not only in their own field, but also in other important fields of science, and to give them a heightened awareness of the aims and potentialities of Brookhaven National Laboratory.

Before describing some rerent research or the novel desiyn und possible uses of a machine or apparatus, the lecturers attempt to familiarize the audience with the background of the topic to be treated and to define unfamiliar terms as far as possible.

Of course we are fully conscious of the numerous hurdles and pitfalls which necessarily beset such a venture. In particular, the difference in outlonk and method bc tween physical and biological sciences presents formidable difficulties. However, if we wish to be aware of progress in other fields of science, we have to consider each obstacle as a challenge which can be met.

The lectures are found to yield some incidental rewards which heighten their spell: In order to organize his talk the lecturer has to look at his work with a new, wider perspective, which provides a satisfying contrast to the often very specialized point of view from which he usually approaches his theoretical or experimental research. Conversely, during the discussion period after his talk, he may derive valuable stimulation from searching questions or technical advice received from listeners with different scientific backgrounds. The audience, on the other hand, has an opportunity to see a colleague who may have Inng heen a friend or acquaintunce in a new and interesting light.

The lectures are being organized by a committee which consists of representatives of all departments of the Laboratory. A list of the lectures that have been given and of those which are now scheduled nppears on the back of this I epurt.

Gertrude Scharff-Goldhaber

The drawing on the cover is taken from a 5th Century B.C. relief on the Acropolis in Athens, the "Dreaming Athena," by an unknown sculptor. 
The Impact of Isotopic Tracers on Physiological Concepts

JAMES S. ROBERTSON

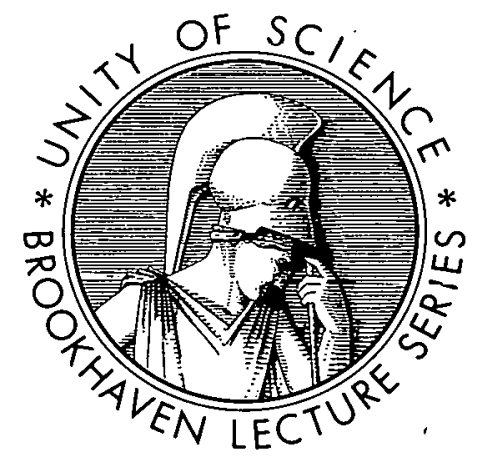

BROOKHAVEN LECTURE SERIES

Number 33, February 12, 1964 


\section{FIA A NOTICE}

This report was prepared as an account of Government sponsored work. Neither the United States, nor the Commission, nor any person acting on behalf of the Commission:

A. Makes any warranty or representation, expressed or implied, with respect to the accuracy, completeness, or usefulness of the information contained in this report, or that the use of any information, apparatus, method, or process disclosed in this report may not infringe privately owned rights; or

B. Assumes any liabilities with respect to the use of, or for damages resulting from the use of any information, apparatus, method, or process disclosed in this report.

As used in the above, "person acting on behalf of the Commission" includes any employee or contractor of the Commission, or employee of such contractor, to the extent that such employee or contractor of the Commission, or employee of such contractor prepares, disseminates, or provides ari:ss 11 , any information pursuant to his empluyment or contract with the Commission, or his employment with such contractor.

\section{PRINTED IN USA \\ PRICE 5 CLEN'I'S

$$
1,00
$$

$\therefore$ Available from the

Office of Ter.hnical Services

Department of Commerce

Washington 25, D.C. 


\section{INTRODUCTION}

Welcome to this 33rd Brookhaven Lecture. I am particularly pleased to introduce this evening's speaker, Dr. James Robertson. Although not one of the first Laboratory employees, Dr. Robertson has been here for a number of years and is well known to most of you.

Dr. Robertson was raised and received much of his formal training in Minnesota, but he actually is a Southerner by birth and spent the first years of his life in Virginia. $\mathrm{He}$ attended the University of Minnesota Medical School, where he obtained his M.D. in 1945. He interned with the Navy at the U.S. Naval Hospital at Annapolis and then spent some months on a Navy destroyer. I first encountered him in 1947, when we were both taking postgraduate work at the Donner Laboratory in Berkeley with Drs. John Lawrence, Hardin Jones, Cornelius Tobias, and the late Jnseph Hamilton. I remember Jim well at the Donner Laboratory, operating a deuterium falling drop apparatus in one room and a small mass spectrometer in another room down the corridor. He certainly looked busy enough, but I was never too sure how much data he actually collected. These machines were homemade and crude, and there was an art to keeping them operative. As near as I could make out, when one became operative so he could start collecting data, he had to leave to start fixing the other one. He must have gotten some data, however, because he was awarded a Ph.D. in physiology by the University of California in 1949.

Dr. Robertson joined the Medical Staff here at Brookhaven in February 1950. He contributed greatly to the development of the Medical Department, particularly, initially, in the areas of setting up and standardizing procedures for use of isotopes, and in dosimetry. However, the Navy apparently was so impressed and pleased with his initial performance at Annapolis that he received another rather formal, rather insistent invitation to spend two more years in that Service. He left Brookhaven to complete this obligatory duty, and we spent two additional years together at the Naval Radiological Defense Laboratory in San Francisco. He returned to Brookhaven at the end of his military leave in Felur uary of 1855 and has been here since.

Dr. Robertson has always had a keen interest in mathematics and physics as well as in medicine and biology, and his knowledge of mathematics is almost unbecoming to a physician. Although his research interests and activitics are broad, his principal scientific contributions have been in the field of tracer kinetics, both on the theoretical and the experimental sides. His studies have inevitably led him into the use of computers, and at present he is duing his best to compulerize the Medical Department, with some appreciable measure of success. His scientific contributions in physiology, biophysics, and tracer theory have been quite substantial, and his reviews on tracer theory are widely regarded as standard and authoritative works in this field. I know of no one more qualified to speak on the subject that he has chosen, "The Impact of Isotopic Tracers on Physiological Concepts."

VICTOR P. BOND 


\section{The Impact of Isotopic Tracers on Physiological Concepts}

Four score and seven years ago* isotopes hadn't been thought of. In trying to fit the occasion by citing something pertinent and important that happened 87 years ago (1877), the closest thing that I found was Edison's invention of the phonograph, which seems at best only remotely related to the present subject. George Hevesy, the originator of the use of isotopic tracers, wasn't born until 8 years later (1 August 1885). ${ }^{1, \mathbf{p} .11}$

Now the use of isotopic tracers has become so extensive that it would be an impossible task to review in one evening their applications in physiology. Hundreds of articles appear every year, and in some areas of research the use of tracers has become so well established and so commonplace that frequently the use of a tracer in an investigation isn't even mentioned in the title of the report. If our attention is restricted to concepts, however, the material to be discussed becomes much more limited. Even so, it has been necessary to select a few outstanding examples and to omit much of perhaps equal importance. Some of the omitted topics have been covered in previous lectures in this series and others will be treated in futurc ones.

To begin with a few definitions, it presumably would be safe to assume that this audience does not need a definition of the term "isotopic tracer." However, for the record, let us briefly say that a tracer is a labeled form of a substance that is, for practical purposes at least, identical in behavior with its unlabelcd counterpart at the level of unit rcaction. An isotopic tracer, of course, is one in which the label is an isotope, which may be stable or radinactive.

It may be more interesting to try to define what is meant by "physiology." A literal translation of the original ancient Greek roots would make it mean the study of physics (physics + knowledge). For ages the term "physiology" was used to mean all natural science and was applied impartially to the animal, vegetable, and mineral kingdoms. ${ }^{2}$ The exclusion of inanimate matter did not occur before the 16 th century. As the various disciplines developed, physiology became more restricted to the

*This lecture was delivered on Lincoln's Birthday. study of living processes. When used without qualifying adjectives, as in general physiology or plant physiology, the term "physiology" now usually means the study of living processes in mammals.

For centuries the concept of a mysterious "vital force" was employed to explain the differences between living and nonliving matter. Life was regarded as a struggle between the vital forces and those of chemistry and physics, with the latter eventually overcoming the former and destroying the body at death. It was only about 100 years ago (1852) that Ludwig discredited the principle of vitalism and expounded upon the doctrine that living processes obey the same laws of chemistry and physics that all other matter does. ${ }^{3}$ An appealing modern definition of physiology is the attempt to explain living processes in terms of chemistry and physics. It should be mentioned, however, that the process of attrition is still going on, and about as fast. as a process actually is explained in terms of chemistry and physics, it tends to be taken out of physiology and to became part of biochemisiry or biophysics, so that what seems left for "pure physiology" are those areas that have not yet been so explained. In addition, the iriroads of anatomy, pharmacology, psychology, hematology, nutrition, genetics, and other independent disciplines on the domain of physiology have been discussed by others to the point of questioning whether there remains a field of physiology per se. ${ }^{4,5}$ We shall ignore the. fine points of the definition and consider all living processes as being within the field of physiology.

The halance of this lecture will be divided into three main parts: (1) an historical backgruund in: tended to describe the state of thinking at the time of the discovery of radioisotopes; (2) the qualitative aspects of some basic discoveries made possible by and through the use of radioisotopes; and (3) analytic interpretation of the kinetic behavior of tracers - the quantitative aspects of tracer theory.

\section{HISTORICAL BACKGROUND}

The reason for inserting an historical background at this point is not only to indicate the place of the tracer method in physiology but also to introduce 
the context of the interdependence of the sciences in general. When we say that much of physiology has not been explained in terms of chemistry and physics, this should not be construed to mean that we doubt that these areas will ultimately be explained - it is largely a matter of these problems being too difficult to attack at present, so that progress must await the development of appropriate physical and chemical methods.

This dependency of progress in physiology on the development of techniques in the more basic sciences is emphasized, because the discovery of radioactive isotopes and the development of the tracer method is just one of many possible examples characterizing the present era in which progress in one field has followed at first apparently unrelated discoveries in another field. Much of the recent progress in the biological sciences has come about through improvements in methods and in instrumentation that have been made by nonbiologists

The dependence of one branch of science on the state of development of another is, of cuurse, an old idea. It was suggested about 100 years ago by the French philosopher Comte, who predicted first a divergence, then a convergence of the sciences. He listed the sciences in such a way that each depends on the preceding science but is independent of those that follow. ${ }^{6}$ As improved by Spencer, the list runs: Mathematics, Physics, Chemistry, Biology, Psychology, and Sociology. For example, as has been discussed by I. e Corbeiller, ${ }^{6}$ Inathematics can be, and often is, presented without any reference to the physical world. Physics uses mathematics but avoids chemical reactions, and sn on, until we reach sociology, the most complex, but which is still so much in the descriptive phase that its inclusion as an experimental science may be questioned. Tolman ${ }^{7}$ explains that although mathematics is the simplest of the sciences, "it is hard for you and me to understand, nor bersanse the mulheinaticlan talks about complicated things, but because he says such complicated things about them." The sciences remain independent during their descriptive phases, but as they becomc experimental and predictive, progress becomes more dependent upun the state of the more basic fields. This sequence is both logical and historical. With this mutual dependency in mind, let us go back even further for a moment. As the Red Queen advised Alice, you should start at the beginning.

Shurtly preceding Aristotle there was a brilliant philosopher named Empedocles, ${ }^{8}$ who was a disciple

\begin{tabular}{llll} 
QUALITY & ELEMENT & BODY HUMOR & TEMPERAMENT \\
\hline HOT + DRY & $\rightarrow$ FIRE & $\rightarrow$ BLOOD & $\rightarrow$ SANGUINE \\
COLD + MOIST $\rightarrow$ WATER & $\rightarrow$ PHLEGM & $\rightarrow$ PHLEGMATIC \\
ORY + COLD $\rightarrow$ EARTH & $\rightarrow$ BLACK BILE & $\rightarrow$ MELANCHOLIC \\
MOIST + HOT $\rightarrow$ AIR $\rightarrow$ YELLOW BILE & $\rightarrow$ CHOLERIC
\end{tabular}

Figure 1. Empedocles to Hippocrates. The ancient Greek theory of the universe and some relationships among the "elements" and certain biological properties.

of the Pythagorean school. The Pythagoreans were fascinated by numbers, especially the number 4 . On this basis, Empedocles decided that all the properties of matter were the result of various combinations of four principles: warm, cold, dry, and moist. The combinations shown in Figure 1 gave the four fundamental elements: earth, air, fire, and water. These elements werc supposed to explain the workings of the univcrse. If Empedocles were working today, he would be a theoretical physicist.

Witl physics and chemistry in such a fix, one could hardly expect much of biology. The body was thought of as being rather like an orange insofar as the organization of its juices was concerned, except that there were some four varieties: blood, phlegm, black bile, and yellow bile, the predominance of one or the other being responsible for the temperament as indicated in the last column of Figure 1 . The purpose of respiration was supposedly to cool the blood, and the role of food was as a lubricant for the motion of muscles and joints. Absurd as these ideas seem to us now, they held sway for centuries, and vestigcs of them remain in our vocabulary today in the terms for temperament.

It wasn't until 1628 that Harvey described the circulation of the blood. Harvey's book on the motion of the heart and binnd ${ }^{9}$ io one of the most important books in the history of physiology, and has been said to mark the beginning of physiology as an experimental science. This noriurred at ubout the same time that Galileo was discovering the moons of Jupiter with his newly invented telescope (1610) and allegedly was dropping weights from the leaning tower of Pisa. Harvey's discovery is cited here not only because of its great phyriological impurtance, but as the outstanding example of a discovery that was made by observation within the realm of biology, that is, without depending on help from other disciplines except for a certain amount of arithmetic. It may he pointed out that the microscope was not available to Harvey, and thcrefore the passage of the blood from arteries to veins could not be explained at that time. Isotopes, 


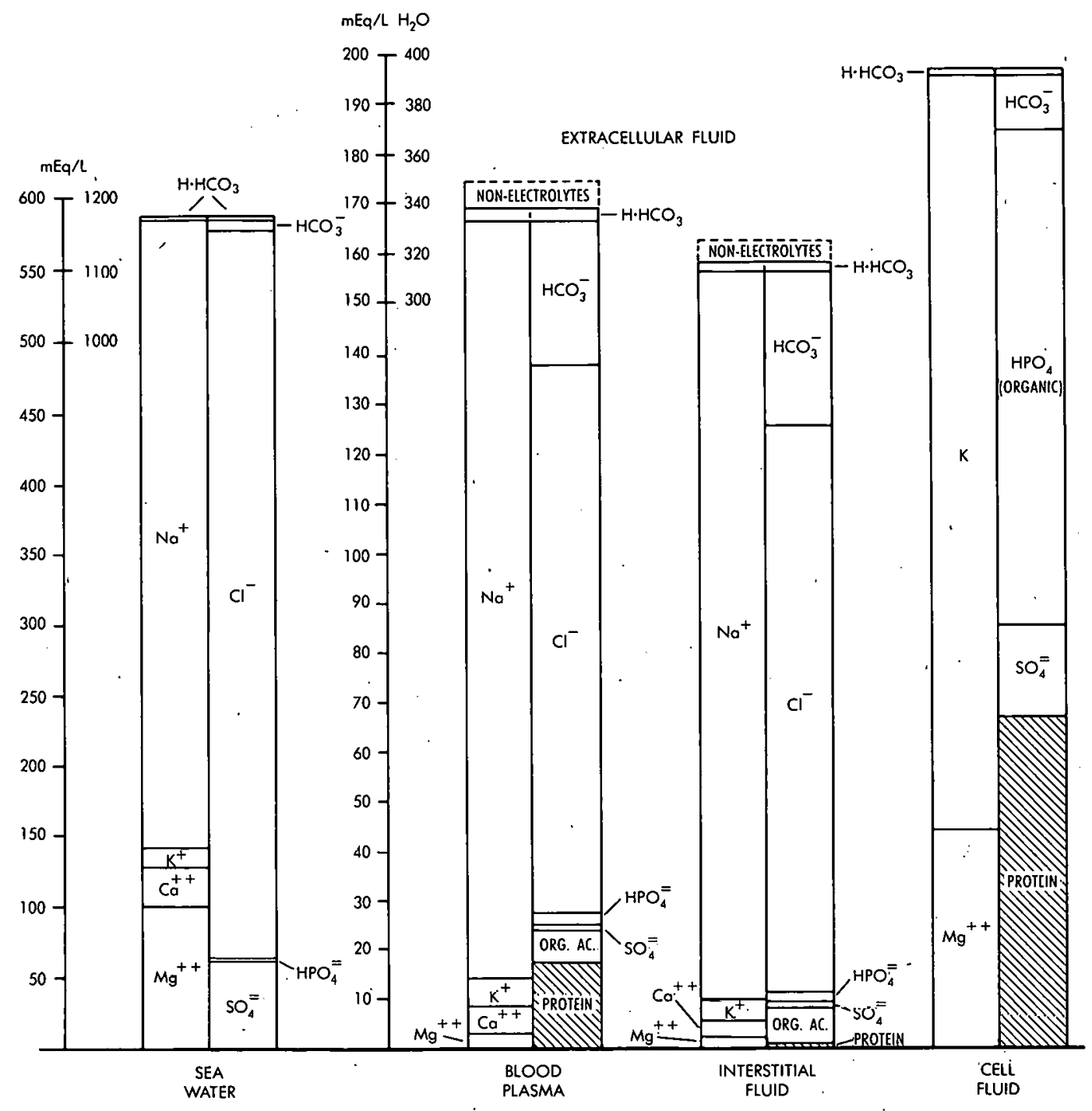

Figure 2. Diagrams of the electrolyte compositivi of body fluids and sea water. Shown here primarily to emphasize the high $\mathrm{K}$, low $\mathrm{Na}$ of cell fluid vs the low $\mathrm{K}$, high $\mathrm{Na}$ of the other fluids. From Gamible."

like the microscope, are among the useful tools that biology has acquired from physics.

With the discovery of oxygen, the role of respiration in the body began to be understood. The body became likened to a candle, and later to an internal combustion engine which requires fuel (food) and air to support a form of combustion, thus generating heat and being capable of achieving mechanical work. It was recognized that food was alsu needed for growth and that the body dif- fered from a machine in that it could repair itself to a degree. Aside from growth and repair, however, the body constituents were regarded as being rather fixed, once they were formed. Not only were bones, teeth, and eyes regarded as being fixed structures but, except for metabolites (that is, the 'various kinds of food in the form that reaches the cells), oxygen, $\mathrm{CO}_{2}$, and other metabolic products, the constituents of cells were regarded as being quite permanent.

One of the biological facts that required explanation, for example, was the difference between the internal composition of cells and the composition of their surroundings, as shown in Figure $2 .{ }^{10}$ There is a relatively high intracellular potassium and a low extraccllular potassium, and the ques: tion is, how is such a gradient maintained? The problem would be resolved if it could be shown that the potassium in the cell was trapped there and couldn't get out. This could happen if the cell 
membrane were impermeable to potassium so that it couldn't pass in either direction. The experiment 'of suspending cells in a potassium-free medium and observing that potassium does leak out is open to the criticism that an unphysiological situation has been used and the results are therefore questionable. Before isotopes were available, some very competent workers had decided to resolve the question, and, as the result of a series of careful experiments, reached the conclusion that the red cell membrane was impermeable to sodium and potassium. ${ }^{11}$ Of course we now know that the conclusion was incorrect. We shall return to this problem later - for the moment it has been mentioned only to illustrate the situation that existed.

\section{THE DYNAMIC STATE OF BODY CONSTITUENTS}

We are now ready to discuss the tracer method. The tracer ronrept itcelf is, of buurse, an ancient one and consists in essence of being able to label or tay some members of a group and, by observing the tag, learn something about the behavior of the group. The genius who first put a bell on a sheep as a means of helping to locate his flock may have originated the method.

Physiologists had long been familiar with the use. of dyes as tracers for studies of the circulation. ${ }^{12}$ The big advantage of an isotopic tracer is, of course, its chemical near-identity with the element being traced. Another advantage, especially with radioactive tracers, is that they can be introduced in quantities sufficiently small that the system under study is not disturbed.

George Hevesy started the use of radiotracers in 1923 when, after two years of unsuccessful effort to separate radium $D$ from lead, he decided that it was practically impossible, and that radium $D$ could be used as a tracer for lead. ${ }^{1, p .14}$ Following a number of investigatione with tracers in such chemical problems as the solubility of difficultly soluble compounds and self-diffusion in metals, Hevesy turned to biological studies. In 1924 he reported studics of the circulation of bismuth and lead in the hody. These clements are, of course, not important as natural constituents of the body, but bismuth, at least, did have some then-current importance in certain therapeutic procedures.

Despite the relatively early availability and attractiveness of radioactive tracers, however, some of the most important work, insofar as the impact on physiological concepts is concerned, was achieved with stable tracers, deuterium and nitrogen-15. Even at that time it was recognized that an isotope of carbon would be closer to being ideal, but none was then available.

In 1934 Rudolf Schoenheimer ${ }^{12}$ and David Rittenberg teamed up and developed the idea of using deuterium (which had been discovered by Urey in 1932) as a label in organic compounds for studies of intermediary metabolism. Those of you who heard Dr. Bigeleisen's talk ${ }^{13}$ are aware of the hazard of an isotopic effect in these studies. Although, of course, the theory of isotopic effects hadn't been worked out, the possibility of an isotopic effect affecting the results of the early studies was not overlooked. The experiments were justified on the basis of the observation that the hydrogen in organic matter has the same isotopic composition as that of common water.

Among the early "surprises" was that, if niinuals (rats) were fed fats containing labeled deuteriostearic acid, a large proportion of the label was rapidly deposited in the body fats. Not only did labeled fats appear in the fat depots, but, if the animals were given heavy water, deuterio-fatty acids appeared in the fat depots and reached a maximum in a strikingly short time. This occurred even in animals that were losing weight. Also, with reversion to the normal unlabeled diet and ordinary water, the isotopic label in the fats disappeared equally rapidly. This work not only showed a rapid interchange between components of the diet and of the tissues, but provided a basis for the study of many intermediate reactions. Interestingly enough, the only natural fatty acids which appeared not to be synthesized by the rat were the highly unsaturated acids known to be essential for health. This supported the idea that the reason these essential fatty acids have to be included in the diet, while others may he nmitted, is that the body does not have the ability to synthesize the essential ones as it does the others.

Similarly, when $\mathrm{N}^{15}$ became available, Schoenheimer and his collcagues used it in studies of protein metabolism. Labeled a mino acids fed to animals in nitrogen equilibrium were found to be rapidly and extensively incorporated into the tissue proteins.

The result of these investigations has been the development of a concept of metabolic "regeneration," meaning a continual release and uptake of chemical substances by tissues to and from a circulating metabolic "pool." This concept has been 
summarized as The Dynamic State of Body Constituents, the title of a little book by Schoenheimer, ${ }^{12}$ from which the preceding discussion was abstracted.

These experiments opened the gates to large areas of investigation that had previously been inaccessible. With the fact of the dynamic state of body constituents established, physiologists and biochemists were attracted to the possibilities of using tracers in investigating the problems of metabolic pathways and turnover rates.

Among the pioneer users of these new ideas was, again, George Hevesy. ${ }^{1}$ After a series of important tracer studies in chemistry, this most remarkable man had turned to biological experiments. Hevesy seems to have tried to study everything. He initi-

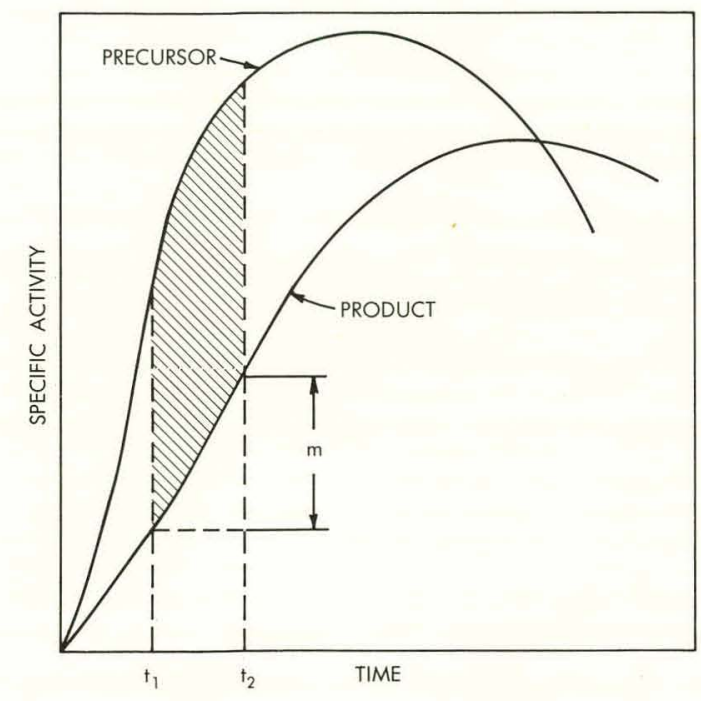

Figure 3. Specific activity-time relationships between product and precursor. From Zilversmit et al. ${ }^{14}$

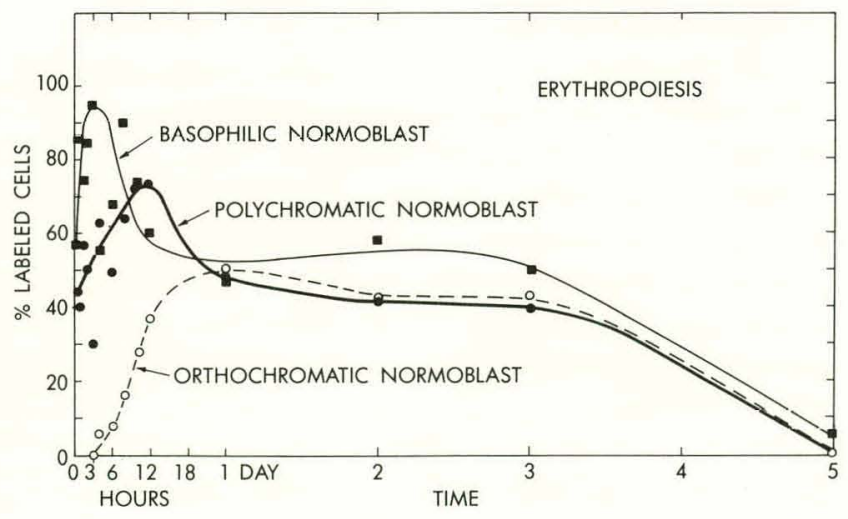

Figure 4. Time course of tritiated thymidine labeling of hematopoietic series. From Bond et al. ${ }^{17}$ ated studies of phosphorus metabolism in rats, including early papers on phosphorus exchange in teeth, the rate of rejuvenation of the skeleton, and retention of atoms of maternal origin in the adult white mouse. In the last-named study he concluded that it takes 11 generations before no phosphorus atoms from the original mother appear in the offspring. (Since the diminution is exponential, and therefore theoretically never reaches zero, this is evidently a statistical zero.)

With other isotopes Hevesy studied red blood cells, body water, potassium exchange, iron metabolism, nucleic acid formation, and many other biological systems or processes. Even now, anyone embarking on a new project concerning the use of isotopes in biology would be well advised to check first to see whether Hevesy has already done it.

Zilversmit et al. ${ }^{14}$ made a significant contribution to the quantitative aspects of the turnover concept by analyzing the specific activity relationships between metabolic products and their precursors. In Figure 3 the slope of the product curve is positive up to the time the curves cross, after which the slope is negative. It can be shown that in a direct precursor-product relationship the specific activity curves should cross at the maximum of the product curve. Equations based on these relationships make it possible to calculate the turnover rate of the product molecule regardless of the shape of the precursor curve. These relationships are modified when the precursor is not the immediate precursor of the product, and when a given product has multiple precursors. There have been many applications of the precursor-product relationship in the biochemistry of intermediate metabolism of fats, carbohydrates, and proteins.

An example at a more definitely physiological level is in the study of the formation of blood cells. ${ }^{15}$ One theory has it that a single type of cell, called the stem cell, gives rise to the multiplicity of cell types that are to be found in the bone marrow and in the blood. A great deal of work has been devoted to the problem of establishing the chain of cell types between a given blood cell type and the stem cell. Tritiated thymidine, a labeled compound developed at BNL by Hughes, ${ }^{16}$ is very useful in such studies. Using labeled thymidine, Bond et al. ${ }^{17}$ have found, for example, that in the chain leading to the formation of the red cell, the label appears in different cell types at different rates, as shown in Figure 4. These curves can be used as part of the evidence for the sequence in the chain 
of cell types and can be used for measuring the time constants for the various cell types. Similarly, the lifetimes of various cell types can be measured. For the blood cells these lifetimes range from a few days for white cells to 120 days for red cells.

\section{PHOTOSYNTHESIS}

The methods used in studying complicated metabolic pathways are perhaps best illustrated by the work of Calvin et al. at the University of California in the now classic study of the path of carbon in photosynthesis. ${ }^{18,19}$ Photosynthesis is, of course, the process by which green plants use sunlight as a source of energy in building carbohydrates $\left(\mathrm{CH}_{2} \mathrm{O}\right)_{x}$ from $\mathrm{CO}_{2}$ and water. Free oxygen is also released in this process. 'I'he over-all reaction is usually represented as

$$
\mathrm{CU}_{2}+\mathrm{H}_{2} \mathrm{U}+h \nu \rightarrow \frac{1}{x}\left(\mathrm{CiH}_{2} \mathrm{O}\right)_{x}+\mathrm{O}_{2} .
$$

In the apparatus used in some of the studies at the University of California, incandescent lights of 1000 to 10,000 foot candles served as a source of artificial sunlight. Green algae (Chlorella and Scenedesmus) contained in a flask between the lights could be exposed to light or to darkness at the will of the investigators. Provision was also made for the rapid introduction and mixing of $\mathrm{CO}_{2}$ labeled with carbon-14. Another important feature of the apparatus was that the contents could very quickly be dumped into boiling absolute ethanol, which stopped all metabolic reactions. With this apparatus the investigators searched for the first products of photosynthesis. Working with increasingly shorter exposures to light and labeled $\mathrm{CO}_{2}$, they continued to find many labeled compounds. Finally, to make a long story short, they had to reduce the overlap of the light and the $\mathrm{CO}_{2}$ exposures to zero, that is, to expose to $\mathrm{CO}_{2}$ after the light was off. The light absorption and the $\mathrm{CO}_{2}$ utilization are separate processes. The light produces an energy state in the plant so that it can pick up $\mathrm{CO}_{2}$ in the dark. There is evidence that the initial energy conversion reaction is associated with the separation of the water molecule into a reducing agent and an oxidizing agent. After $\mathrm{CO}_{2}$ exposures of 90 seconds, some 15 labeled compounds could be identified by the technique of making auto radiographs from paper chromatographs. Figure 5 shows typical autoradiochromatographs. When the exposure was reduced to 5 seconds, there were only 4 or 5 compounds and $65 \%$ of the fixed $\mathrm{C}^{14}$ was in 2- and 3-phosphoglyceric acid, which were apparently the first products to be labeled.

Diphosphates of fructose and glucose are also among the compounds labeled very early, and these combine to form sucrose in at least one of the proposed mechanisms. Sucrose is the first free sugar
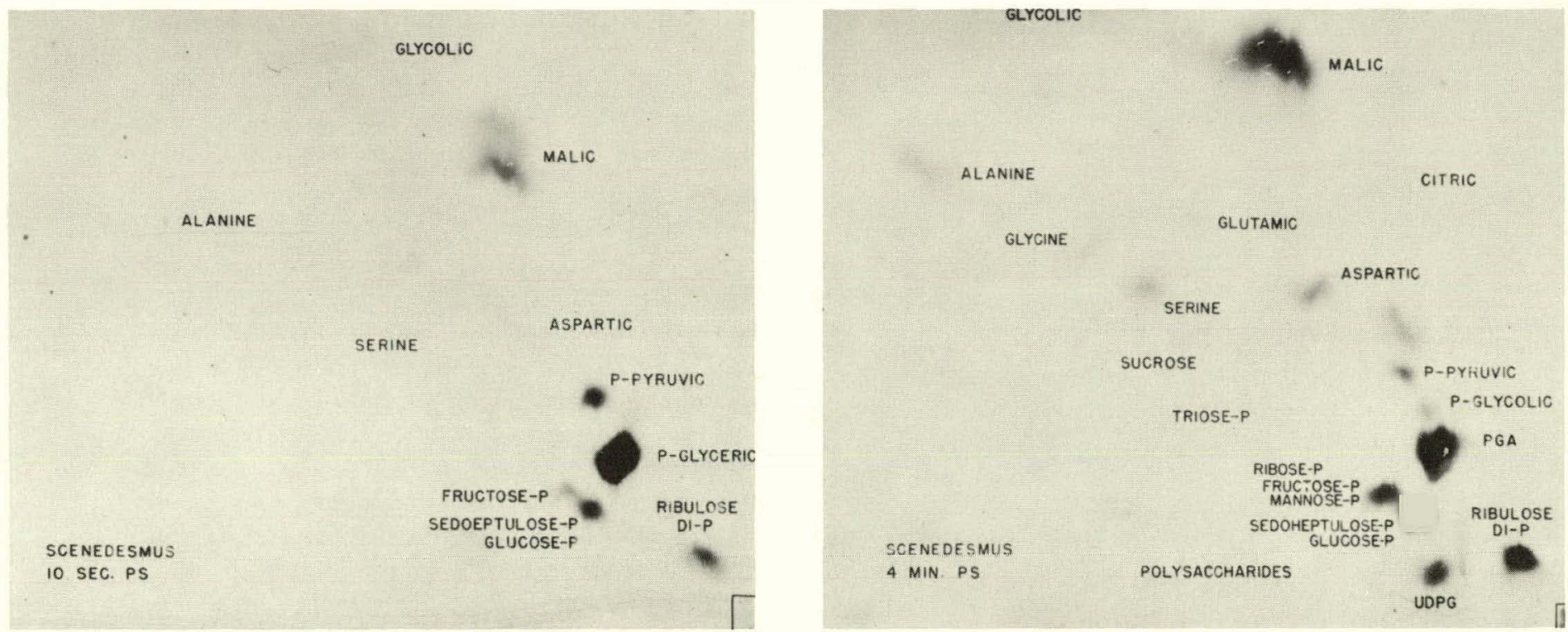

Figure 5. Autoradiographs of paper chromatographs of $\mathrm{C}^{14}$-labeled products of photosynthesis in green algae. Courtesy of A.A. Benson. 
to appear. As illustrated in Figure 6, the $\mathrm{CO}_{2}$ carbon enters a cycle of successive compounds connected through a series of reactions. The only precursor necessarily common to carbohydrates, fats, and amino acids is 3-phosphoglyceric acid. Some plants, such as the sugar beet, incorporate most of their incoming carbon into carbohydrate, but with tracers it has been shown that fats and amino acids can be produced without intervention of hexose intermediates.

Similar $\mathrm{CO}_{2}$ fixing cycles occur in mammalian systems, but of course only in green plants is light the source of energy. Incidentally, it may be mentioned that Ruben, ${ }^{20}$ using oxygen- 18 as the label, showed that the oxygen that is evolved in photosynthesis originates entirely from water, not from $\mathrm{CO}_{2}$.

In respiration, there is a similar cycle that runs in the opposite direction in the sense that carbohydrates are oxidized to $\mathrm{CO}_{2}$ with an associated release of energy. This is known as the Krebs, or tricarboxylic acid, cycle. The Krebs cycle may also be entered through protein metabolism.

Isotopic studies have made it possible to establish many important relationships among carbohydrates, fatty acids, and proteins. For example, it was shown that while there is some conversion of carbon-14-labeled glucose to fatty acids in other tissues, the liver is 10 times as active in this proc-

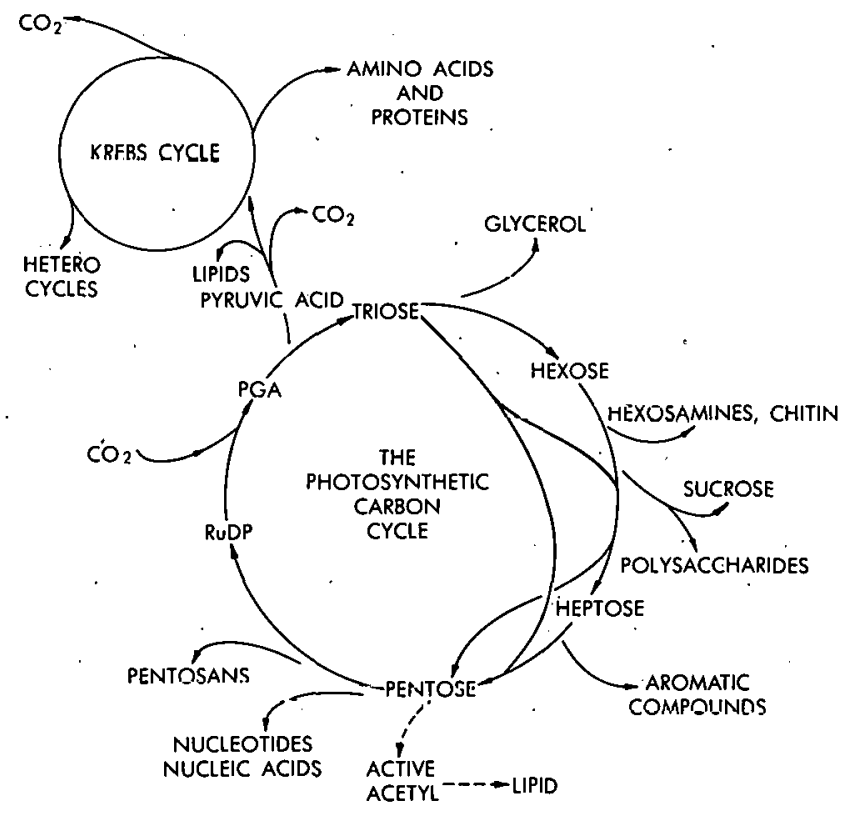

Figure 6. Carbon compound synthesis from carbon dioxide in plants. From Bassham and Calvin. ${ }^{18}$ ess. ${ }^{21}$ One of the major metabolic defects in diabetes is the failure of the ability of the liver to utilize glucose for fatty acid synthesis. It has also been shown that the short-chain fatty acids can be incorporated into glucose, a process that an earlier textbook described as a "figment of the imagination." Insulin controls the conversion in both directions between carbohydrates and fats. It is also possible that insulin exerts much of its control through its effect on protein synthesis. Some of these findings are not only of physiological interest, but have clinical implications that may affect the treatment of diabetes. ${ }^{22}$ When insulin is given to a patient, his blood glucose concentration falls. Without isotopic tracers, it would be very difficult or impossible to determine whether this fall is due to a decreased glucose production rate or to an increased utilization rate, but with tracers each process can be studied independently. Actually both processes may be important, with utilization being the better established. Insulin controls the rate of entry of glucose into muscle and fat cells, and also affects the output of glucose by conversion from glycogen. ${ }^{23}$.

Many pathways besides that of carbon have been worked out with radioisotopes. The course of iodine in the body, as illustrated in Figure 7, is another good example. As is well known, iodine is concentrated by the thyroid gland. However, as

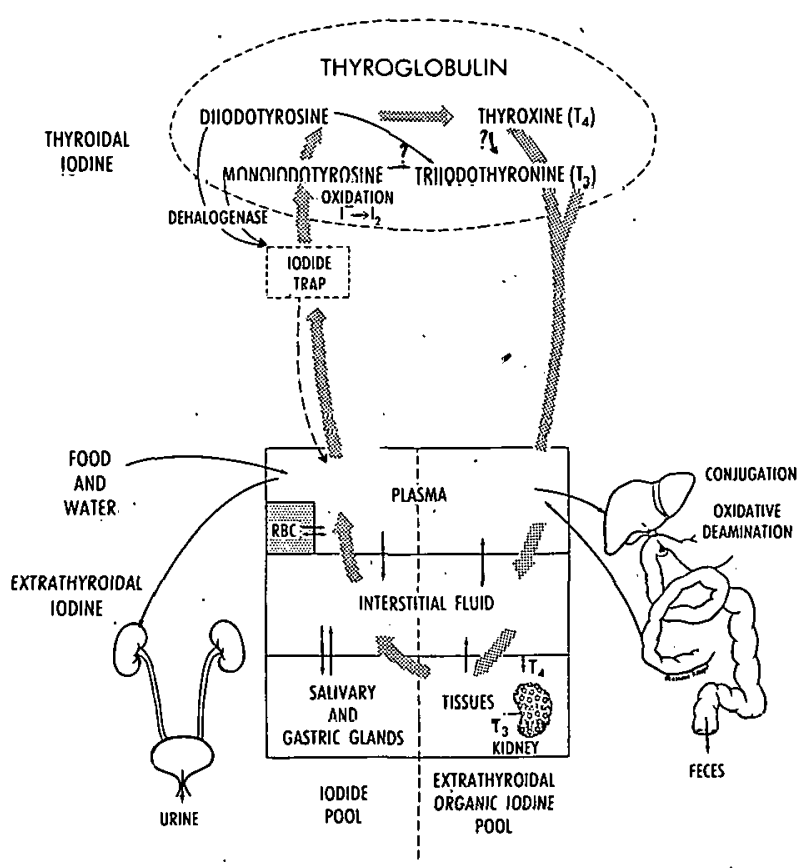

Figure 7. The iodine cycle. From Berson. ${ }^{42}$ 
indicated in Figure 7, the thyroid has to compete with gastric and salivary iodide secretion and with iodide excretion by the kidneys. These other processes can affect the results of thyroid iodine uptake studies. The steps in the synthesis of the thyroid hormone have largely been elucidated through the use of radioiodine. ${ }^{24}$ The importance of being able to use a minute amount of a tracer was brought out in a study of the transport of the thyroid hormone in the blood. ${ }^{25}$ With small amounts of tracer, most of the labeled hormone appears in the globulin fraction of blood plasma, but when larger amounts are used, much of the activity appears. in the albumin fraction,

\section{ANALYSIS OF COMPARTMENTED SYSTEMS}

A large class of substances, such as water and the electrolytes, exist in the body in the same chemical form on buth sides of various anatomical barriers, such as the walls of blood vcssels, the membranes of cells, and the membranes of cell nuclei. Even within the cell there are other structures that are defined by definite boundaries; for example, little bodies called mitochondria: Within fairly recent times there was still some question as to whether mitochondria were artifacts, that is, a result of staining methods used in preparing cells for study, and not natural, living constituents of the cell. Now these structures are recognized as being very important in the energy-producing reactions in the cell. ${ }^{26}$

In all these cases, the item of interest is often simply the rate of passage or transport of substances back and forth across the boundary. To determine these rates it is sometimes sufficient to rely on observations of the behavior of a tracer, without requiring chemical isolation and identification of the substance being traced. This is important, because in work with mammals, and in particular with human beings, it frequently is not possible, or perhaps not permissible, to obtain a sample for chemical analysis. With human beings as the subjects, often the only samples that can be obtained are blood, breath, and excreta. Much as we would like to have them, we can't grab samples of bone, muscle, liver, etc., for analysis whenever we please. Some information about the amount and location of a gamma-emitting radioisotopic tracer, however, can be obtained by external counting methods, particularly with scintillation counters. The design of such counters ranges from those useful for rather precise geometric localization of activity to whole-body counters that are used to assess the total amount of a tracer in the body. In these studies the interpretation of the behavior of the tracer is heavily dependent on mathematical analysis of the data. This kind of analysis was originated by Sheppard and Householder ${ }^{27}$ and has subsequently become a very useful procedure. ${ }^{28-30}$ In order to discuss this type of analysis, it is necessary to define a few terms and to point out the assumptions involved.

The system being studied is regarded as consisting of a number of subdivisions called compartments. It is assumed that in what is called the steady state, the unlabeled composition of each compartment remains constant, so that the rates of flow in and out are equal. It is also assumed that within a given compartment mixing is perfect; that is, the material of interest is homogeneouoly distributicl throughout the compartment, and that any material entering the compartment is instantaneously mixed with the material present. It is realized that these assumptions are oversimplifications of the real situation, but they are necessary as a starting point for the mathematical analysis and are adequate for many purposes. Modifications may be made later as they are needed. ${ }^{31}$

It should be mentioned that a compartment does not have to be defined in terms of anatomical boundaries. A compartment may be a chemical state or a functional sủbdivision. It may even have a shifting location. For example, all the cells in the DNA synthesis stage of mitosis at one time may be regarded as a compartment for some purposes.

Another extremely important assumption concerns the behavioral identity of the tracer with the material being traced. It is assumed that, at the level of the unit being considered, the labeled material behaves just like ito unlabeled counterpart with respect to participation in chemical reactions and with respect to reaction kinetics. When the unit that is labeled is a cell or a large molecule, isotopic effects are negligible. In some reactions at the atomic level, huwever, the isotopic effect may have to be considered. ${ }^{13}$ There is no question, for example, that heavy water $\left(\mathrm{D}_{2} \mathrm{O}\right)$ behaves diffcrently, in the body than does $\mathrm{H}_{2} \mathrm{O}$, because it has repeatedly been shown that $\mathrm{D}_{2} \mathrm{O}$ is toxic to mice and rats. ${ }^{32}$ These animals die when the heavy water concentration in their body exceeds about $30 \%$. It may be noted, however, that somc plants can be essentially 100\% deuterated, 
and this opens up the interesting speculation that it may be possible to breed mammals with a progressive tolerance for $\mathrm{D}_{2} \mathrm{O}$ in succeeding generations. An isotopic effect can even be shown in some carbon reactions.

In most physiological studies, however, it may be assumed that the isotope effect is negligible. Formally, this assumption is expressed by using the same turnover rate constant, $k$, for both the labeled and the unlabeled material:

$$
\frac{\rho}{S}=k=\frac{\rho x}{S x}=\frac{\rho^{*}}{Q},
$$

where $S=$ the amount of the substance being traced within a given compartment, $\rho=$ the rate of flow of the substance, $x=$ specific activity of the tracer in $S, \rho^{*}=$ rate of flow of the tracer, and $Q=$ total amount of the tracer in $S$.

With these assumptions, the differential equation describing the behavior of the tracer with some starting value, $x_{0}$, in the compartment and with no tracer in the inflow is just like the one that describes radioactive decay, with the turnover rate constant being analogous to the decay constant. Of course, the solution equation, $x=A e^{-\lambda t}$, is analogous also, and the curve that describes the disappearance of the tracer from a single compartment is the familiar exponential decay curve. Thus by determining the rate constant, $\lambda$, for the curve that describes disappearance of the tracer; one obtains the turnover rate constant for the unlabeled substance in the compartment. To get the absolute valuc of the turnover rate, it is neçessary to know the amount of $S$. Alternatively, if $\rho$ is known, $S$ can be calculated. The convenient equality between the turnover rate constant and thc cxponent in the solution equation also holds for multicompartment systems having "one-way traffic." In chains of compartments with no fecdback, it can be shown that the solution equation will have several exponential terms and each exponent will correspond to one of the turnover rate constants, again in analogy with the decay of mixtures of radioactive isotopes or chains of parent-daughter isotopes.

When there is feedback, hnwever; as in the twocompartment closed system, the relationships between the rate constants of the system and the slopes of the curves change. In the two-compartment closed system with the label confined to the first compartment at time zero, the solution equations

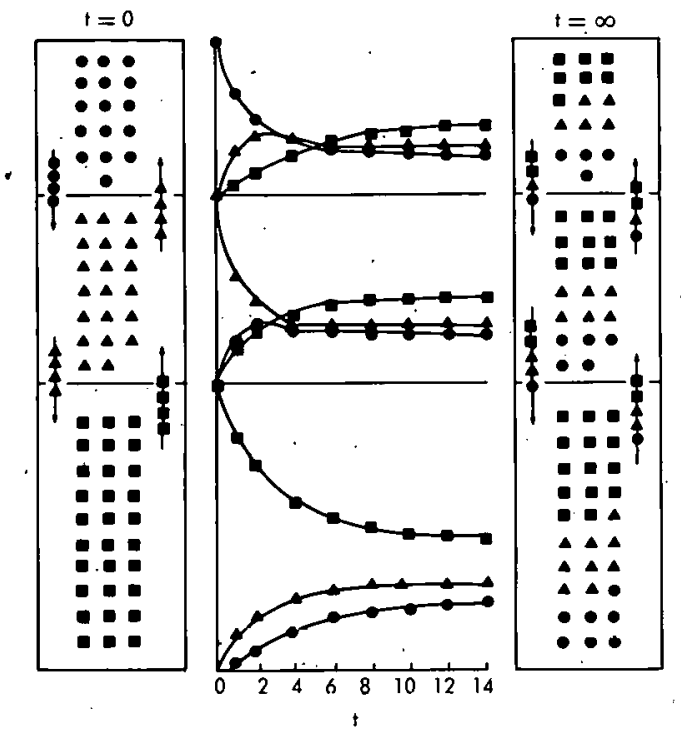

Figure 8. Redistribution of labeled substances in a threecompartment closed system in the steady state. From the initial conditions indicated in the left diagram, the labeled material is redistributed among the three compartments according to the curves in the middle until a final equilibrium condition indicated on the right is reached. In this system, analysis of any one of the disappearance curves provides all the information needed to calculate the relative sizes of the compartments and the rates of flow between them. In higher-order multicompartment systems, it is necessary to sample several compartments in order to obtain enough information for a complete solution.

$$
x_{1}=A e^{-\lambda t}+B \quad \text { and } \quad x_{2}=B\left(1-e^{-\lambda t}\right)
$$

have only one exponential term, the second having degenerated to a constant, the equilibrium value. The exponential constant, $\lambda$, is the same for both curves, and $\lambda$, instead of being either of the two turnover rate constants, $\rho / S_{1}$ or $\rho / S_{2}$, can be shown to be their sum, $\rho / S_{1}+\rho / S_{2}$. Similarly, in the case of the three-compartment closed system, the solution equations have only two exponential terms and the $\lambda$ 's are the roots of a quadratic equation in which the coefficients are various groupings of the turnover rate constants. The variety of curves that result from the introduction of a tracer into a three-compartment closed system is shown in Figure 8, which illustrates the changes in distribution between time zero and equilibrium.

In going through the equations this way the parameters of the system have been used to predict the behavior of the tracer, as described by the solution equations. The real problem, however, is how to proceed when given the solution equation, 
for example, by fitting a curve to experimental data, and what is required is to deduce the characteristics of the system; in other words, to work the reverse problem. This can be done as follows. If the solution values for $x_{1}, x_{2}$, etc., are substituted back into the original differential equations, a matrix consisting of the product of the rate constants and the coefficients from the solution equation is obtained. Also, if the solution equations are differentiated, derivatives of $x_{1}, x_{2}$, etc., are obtained that can be equated to the original derivatives, but in this case the matrix consists of products of the $\lambda$ 's and the coefficients. Therefore

$$
|k||C|=|C||-\lambda|
$$

and with matrix algebra one can solve for the $k$ 's by using the inver'se of $|C|$ as a post-multiplier:

$$
|k|=|C||-\lambda||C|^{-1} \text {. }
$$

Thus in principle it is possible to solvc for the rate cunstants of the system from the constants (the coefficients and exponents) in the equations that describe the behavior of the tracer. For the twoand three-compartment systems this is simple enough to be achieved by desk calculations, but for more complicated systems the equations are too unwieldy and some help is needed. One approach is to use an electrical analog computer. The equations for the discharge of capacitors through resistors are analogous to those for compartmented systems. Thus a model of the real system can be set up on an analog computer and electrical values can be suitably chosen to obtain curves that fit the data. ${ }^{3 s, s 1}$

Two things should be pointed out at this time. First, the use of an analog computer in this way is not just a fancy curve-fitting method; it is a way of by-passing all the intermediate steps involved in writing and solving differential equations, and provides a means of jumping directly from the data to a model of the system. Second, any model so obtained may or may not be unique for several reasons. In the three-compartment system, for example, the same data can be fitted by one model, assuming that the tracer is originally in one compartment, and by a different model if it is assumed that a different compartment is involved. In this case other information has to be used to make the decision. Another cause of ambiguity is that the data are of a statistical nature, so that any fit is a compromise.
With an analog computer it is difficult to decide which of several possible combinations of values is the best one to use. For this purpose it is often more satisfactory to use a digital computer and a least-squares program for achieving the curvefitting. We are using an IBM-7094 program that was borrowed from Mones Berman. ${ }^{35}$ By an iterative method, this program selects a set of values that gives a least-squares fit between a set of data and a preselected configuration of compartments. The digital computer, on the other hand, is less flexible than an analog computer at the stage of searching for the model, or configuration, to use. Thus a good working procedure is to use an analog computer to search for the model and then to switch to the digital computer for obtaining the best fits and for routine fitting. This program can also be used to give a fit simply in terms of exponential components aud is heing nsed by at least one other group in the Laboratory for this purposc; there is a bit of two-way traffic in the matter of cooperation between the departments of the Laboratory.

Earlier in this lecture I promised to return to the question of the permeability of the red blood cell to sodium and potassium. If a tracer quantity of potassium- 42 is added to a medium in which red blood cells are suspended, it is easily shown that the tracer enters the cells. ${ }^{36}$ Similarly, once the cells are labeled, if thcy are resuspended in a tracer-free medium, the tracer leaves the cells, which shows that the membrane is permcable to potassium in hoth directions. From the tracer data the rate of exchange of unlabcled potassium between red cells and plasma can be calculated by using the two-compartment model discussed above. Thus a tracer experiment simple enough to be used for teaching generates data about a process that only a few ycare ago was inaccessible to investigation. By an extension of this technique, Tosteson ${ }^{37}$ was able to show that the flux of potassium both into and out of the red blood cells of sickle cell ancmia patients was faster than normal under conditions surh that the oolla were lusiug potassium. Modern explanations of the high intracellular potassium content are in terms of active transport and discrimination on the basis of differences in the sizes of the hydrated ions of sodium and potassium.

Another group of studies involves the analysis of the rates of disappearance of labeled materials injected into the circulation. In Figure 9 the inverse 
of the concentration, or the apparent volume of dilution, is plotted for several substances. ${ }^{1}$ It may be seen that $\mathrm{Na}, \mathrm{Br}$, and $\mathrm{Cl}$ level off with apparent volume of dilution of the order of 20 to $30 \%$ of the body water volume. This is consistent with the volume of the cxtracellular fluid. Potassium, however, levels off at $150 \%$. This is possible because potassium has a higher intracellular concentration. The curve for phosphorus doesn't level off because phosphorus is metabolized and continues to leave indefinitely.

Studies of this kind may be used as measures of the circulation rates for various organs because the blood perfusion rate is the rate-limiting process. The true tränscapillary exchange rates are usually much faster and cannot readily be obtained from blood samples only.

It should be pointed out that tracers sometimes create questions rather than providing answers. For example, surprising as it may sound, there is still a controversy in the literature concerning the mechanism of one of the most fundamental of biological processes, the flow of the solvent in osmosis. Figure 10 is an attempt to describe the major opposing views. In the upper left diagram the arrows indicate that diffusion of solvent in the two directions across a membrane is equal. In the diffusion theory (middle left) the presence of a solute reduces the diffusion rate of the solvent, giving a net flow from pure solvent into solution. The hydro-

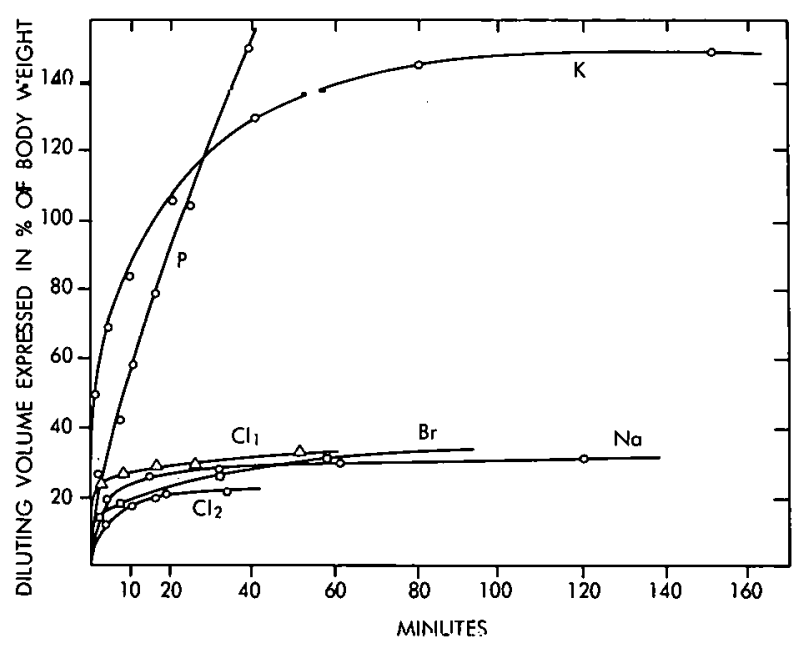

Figure 9. Apparent volumes of dilution of various labeled substances introduced into the circulation. The apparent volume of dilution indicates the distribution of the unlabeled material and the rate of interfusion of the label with its unlabeled counterpart. From Hevesy. ${ }^{1}$
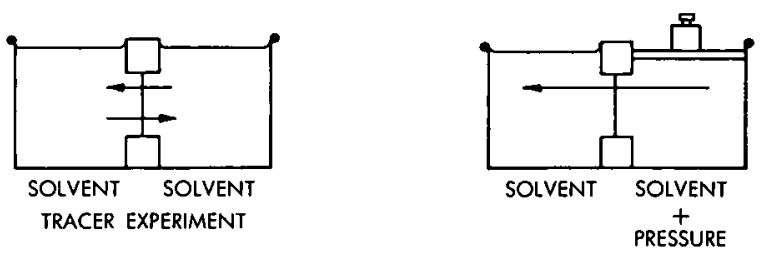

HYDRAULIC EXYERIMENT
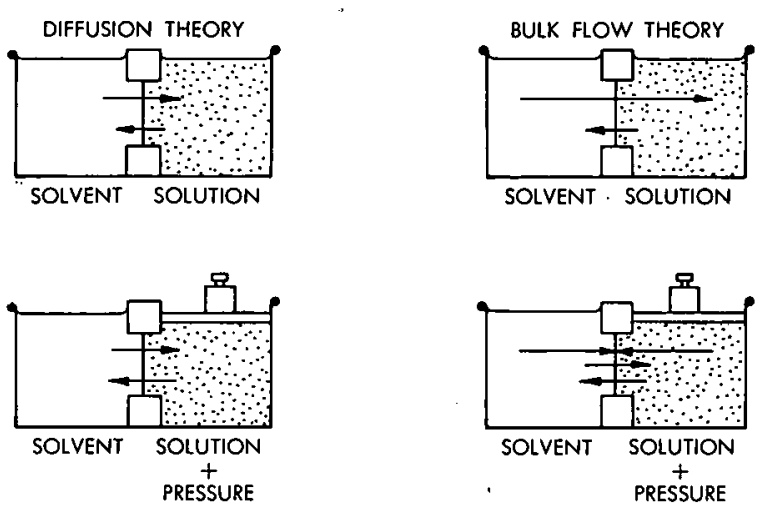

Figure 10. Comparison of the conflicting theories on the mechanism of solvent transfer in osmosis. Explanation in text.

static pressure needed to restore the diffusion rate is a measure of the osmotic pressure ${ }^{s 8}$ (lower left). Mauro, ${ }^{39}$ however, has data indicating that a hydrostatic pressure produces a much greater flow rate per unit of pressure than does diffusion, as measured by the use of $\mathrm{H}_{2} \mathrm{O}^{18}$ labeled water (upper right). In an alternative theory (middle right) the presence of the solute creates a momentum deficiency on the solution side of a pore in the membrane (Onsager, cited in ref. 39), giving rise to a hydraulic pressure, with bulk huw fivin solvent into solution. An applied hydrostatic pressure (lower right) stops this flow by opposing the generated pressure, again leaving diffusion as the remaining component of motion.

Nims has undertaken to resolve the situation through consideration of the balance between electrochemical forces and external forces, concluding that in the osmotic situation the observed flow of the tracer bears little relation to the flow of the substances concerned. ${ }^{40}$ There is evidently still much to be done, both experimentally and theoretically, before these issues are finally decided.

\section{CONCLUSION}

Many additional examples of the applications of the uses of isotopes could be cited, but that is not 
the purpose of this lecture. What I have tried to do is to show that the tracer has made it possible to study such things as the pathways of metabolized substances in the body and the kinetics of steady state systems. These studies have helped change the idea of the body as being composed of fixed constituents to one in which most of the tissues are subject to constant renewal, and have greatly modified our ideas about many living processes and the relationships among body constituents. At the same time I have indicated that this kind of research is one that has resulted from, and still depends heavily upon, ideas and methods from the more basic disciplines. Perhaps I have also indirectly helped to explain why the Medical Department needs pulse-height analyzers, wholebody counters, and computer time.

Finally, to symbolize the progress that has been made in bringing the physical sciences and mathematics into physiology and medicine, I quote a slightly ungrammatical limerick by Lusted: ${ }^{41}$

There was a young Doc from Atlantic

Whose data was all autumätic

To make a house call

Computer and all

He needed a bag most gigantic!

Maybe in the future computers can be miniaturized so that this won't be such a problem.

Ackinweledyments: The author would like to thank Dr. Andrew Benson and the Ciba Pharmaceutical Company for slides used in the lecture hut not ireproduced in this publication.

\section{REFERENCES}

1. Hevesy, G., Adventures in Radioisotope Research (Collected Papers), Pergamon, New York, 1962.

2. Veith, 1., Editor, Perspectives in Physinlog', Americun Physiological Society, Washington, 1954.

3. SмIтн, $\mathbf{H}$., The philosophic limitations of physiology, Ibid., pp. 31-43.

4. Von Muralt, A., Development and limitations of physiological research, Ibid., pp. 9-12.

5. Fenn, W.O., Born fifty years too soon, Ann. Ron. Physinl. 24, 1-1U (1962).

6. Le Corbeiller, P., Stars, proteins and nations, The Atlantic Monthly 178, 78-83 (1946).

7. Tolman, R.C., A survey of the sciences, Science 106, $135-40$ (1947).

8. Dampier, Sir W.C., A History of Sienie, Macmillan, New York, 1949.

9. Harvey, W., De Molu Cordis et Sanguinis in Animalibus, Fitzer, Frankfurt, 1628.
10. Gamble, J.L., Sr., Chemical Anatomy, Physiology and Pathology of Extracellular Fluid, Harvard University Press, Cambridge, 1942.

11. Wakeman, A.M., A.J. Eisenman and J.P. Peters, Study of human red blood cell permeability, J. Biol. Chem. 73, 567-80 (1927).

12. Schoenheimer, R., The Dynamic State of Body Constituents, Harvard University Press, Cambridge, 1942.

13. Bigeleisen, J., Chemistry of Isotopes, Brookhaven Lecture Series No. 30, Oct. 16, 1963. (Not yet published.)

14. Zilversmit, D.B., C. Entenman and M.C. Fishler, Calculation of "turnover rate" from experiments involving the use of labeling agents, J. Gen. Physiol. 26, 325-31 (1943).

15. Stohlman, F., JR., Editor, The Kinetics of. Cellular Proliferation, Grune \& Stratton, New York, 1959.

16. Hughes, W.L., The Renewal of Cells and Molecules - The Fountain of Youth, Brookhaven Lecture Series No. 19, Sept. 19, 1962. (Nut yet published.)

17. Bond, V.P., 'I'.M. Fliedner, E.P. Cronkite, J.R. Rubini and J.S. Robertson, Cell turnover in blood and blood-forming tissues studied with tritiated thymi. dine, pp. 188-200 in ref. 15.

18. Bassham, J.A. and M. Calvin, The Path of Carbon in Photosynthesis, Prentice Hall, Englewood Cliffs, N.J., 1957.

19. Bassham, J.A:, A.A. Belnsún and M. Cialvin, Isotope studies in photosynthesis, $J$. Chem. Educ. 30, 274-83 (1953).

20. Ruben, S., M. Randall, M. Kamen and J.L. Hyde, Heavy oxygen $\left(\mathrm{O}^{18}\right)$ as a tracer in the study of photosynthesis, J. Am. Chem. Soc. 63, 877-9 (1941).

21. Chaikoff, I.L., Metabolic blocks in carbohydrate metabolism in diabetes, in The Harvey Lectures 1.951-52, pp. 99-175, Academic Prcss, New York, 1953.

22. BAKER, N., Metabolism of $\mathrm{C}^{14}$ laheled gluoosc in diabetes, Diabeles 5, 178-85 (1956).

23. Levine, R., Diabetes mellitus, Clinical Symposia (Ciba Pharmuctutical Co.) 15, 1013-32 (1963).

24. Rugas, D.S., Quantitative aspects of indine metabolism in man, Pharmacol. Rev. 4, 284-370 (1954).

25. Freinkel, N., J.'I". Nowling and S.H. Ingbar, The interaction of thyroxine with plasma proteins: localization of thyruxine-binding protein in Cohn fractions of plasma, J. Clin. Invest. 34, 1698-709 (1955).

26. Chance, B., Editor, Energy-linked Functions of Mitochondria, Academic Press, New York, 1963.

27. Shèppard, C.W. and A.S. Householder, Mathematical basis of interpretation of tracer experiments in closed steady-state systems, J. Appl. Phys. 22, 510-20 (1951).

28. Sheppard, C.,W., Basic Principles of the Tracer Method, Wiley, New York, 1962.

29. Robertsun, J.S., Theory and use of tracers in determining transfer rates in biological systems, Physinl. Rev. 37, 133-54 (1957).

30. Robertson, J.S., Mathenatical treatment of uptake and release of indicator substances in relation to flow analysis in tissues and organs, in Handhook of Physiology, Circulation I, pp. 617-44, American Physiological Socicty, Washington, 1962.

31. HART, H.E., Editor, Multicompartment analysis of tracer cxperiments, Ann. N.Y. Acad. Sci. 108, 1-338 (1963). 
32. KritchevsKy, D., Editor, Deuterium isotope effects in chemistry and biology, Ann. N.Y. Acad. Sci. 84, 573781 (1960).

33. Higinbotham, W.A., R.M. Sugarman, D.W. Potter And J.S. Robertson, A direct analog computer for multicompartment systems, pp. 117-21 in ref. 31 .

34. ROBERTSON, J.S. AND S.H. Cohn, Use of an analog computer in studies of strontium and calcium metabolism in man, pp. 122-7 in ref. 31 .

35. Berman, M., M.F. Weiss and E. Shahn, Some formal approaches to the analysis of kinetic data in terms of linear compartinental systems, Biophys. J. 2, 290-316(1962).

36. Danowski, T.S., The transfer of potassium across the human blood cell membrane, J. Biol. Chem. 139, 693705 (1941).
37. Tosteson, D.C., E. Carlsen and E.T. Dunham, Effect of sickling on potassium transport, J. Gen Physiol. 39, $31-53$ (1955).

38. Chinard, F.P. and T. Enns, Osmotic pressure, Science 124, 472-4 (1956).

39. Mauro, A., Nature of solvent transfer in osmosis, Science 126, 252-3 (1957).

40. NIMS, L.F., Tracers, transfer through membranes, and coefficients of transfer, Science 137, 130-2 (1962); also comments, Science 138, 1183 (1962).

41. Lusted, L., in Conference on Data Acquisition and Processing in Biology and Medicine, Rochester, 1961, pp. 3-9, Pergamon, New York, 1962..

42. Berson, S.A., Pathways of iodine metabolism, Am. J. Med. 20, 653-69 (1956). 
20. A Neutron's Eye View of Magnetic Materials Julius M. Hastings, Chemistry Department

21. Landscaping the Groves of Academe

R.C. Anderson, Director's Office

22. Chemical Communication Systems in the Cell Henry Quastler, Biology Department

23. Neutrino Physics, BNL 787

Leon M. Lederman, Physics Department

January 9,1963

24. The Use and Misuse of the Atmosphere, BNL 784

Maynard E. Smith, Instrumentation and Health Physics Department February 13, 1963

25. The Nucleus Today

Denys Wilkinson, Physics Department

March 6, 1963

26. Trace Metals: Essential or Detrimental to Life, BNL 828

George C. Cotzias, Medical Department

April 10,1963

27. The Early Days of the Quantized Atom

Samuel A. Goudsmit, Physics Department

May 15,1963

28. Catalysis in Life and in the Test Tube

Daniel E. Koshland, Jr., Biology Department

June 19, 1963

29. Collisions of "Elementary" Particles With Protons at High Energies Samuel J. Lindenbaum, Physics Department

September 25,1963

30. Chemistry of Isotopes

Jacob Bigeleisen, Chemistry Department

October 16, 1963

31. The Nuclear Reactor Comes of Age, BNL 838

Jack Chernick, Nuclear Engineering Department

November 13, 1963

32. Radio Galaxies

David Heeschen, National Radio Astronomy Observatory

January 15,1964

33. The Impact of Isotopic Tracers on Physiological Concepts, BNL 857

James S. Robertson, Medical Department

February 12, 1964

34. The Biology of Aging, BNL 854

Howard J. Curtis, Biology Department

March 18, 1964

35. The Problem of Development

Ernst W. Caspari, University of Rochester

April 15, 1964

36. Bubble Chambers: Instruments for High Energy Physics Experiments William B. Fowler, Physics Department

May 6; 1964

37. Bubble Chamber Experiments - Alpha to Omega Minus

Nicholas P. Samios, Physics Department

May 20, 1964 


\section{LIST OF BROOKHAVEN LECTURES}

(Those with BNL numbers given have been published or are in press)

1. Radioastronomy and Communication Through Space, BNL 658

Edward M. Purcell, Physics Department

November 16, 1960

2. Current Ideas on the Endocrine Regulation of Cellular Processes, BNL 685 Irving Schwartz, Medical Department

December 14, 1960

3. Inside the Protein Molecule, BNL 649

Werner Hirs, Biology Department

January 11,1961

4. Nuclear Chemistry Research With the Cosmotron

Gerhart Friedlander, Chemistry Department

February 15, 1961

5. Neutron Physics Of and With the High Flux Beam Research Reactor, BNL 664

Herbert Kouts, Nuclear Engineering Department

March 15, 1961

v. High Energy Accelerators, BNL 747

Ernest Courant, Physics Department

April 12, 1961

7. Dislocations in Crystal Lattices

George H. Vineyard, Physics Department

May 17,1961

8. The History of Cosmic Rays and Meteorites, BNL 779

Oliver A. Schaeffer, Chemistry Department

June 14, 1961

9. The Physics of Semiconductor Radiation Detectors, BNL 699

G.L. Miller, Instrumentation and Health Physics Department

September 27, 1961

10. Theory of the Gene, BNL 739

Milislav Demerec, Biology Department

October 18, 1961

11. Fundamental Particles of Physics

Maurice Goldhaber, Director, Brookhaven National Laboratory November 15, 1961

12. Excessive Salt Intake and Hypertension: A Dietary and Genetic Interplay, BNL 733

Lewis K. Dahl, Medical Department

December 13, 19:61

13. Gulaxles, BIVL TIU

Otto Struve, National Radio Astronomy Obseryatory

January 17,1962

14. A Computer Learns To See, BNL 725

Paul Hough, Physics Department

Februạry 14: 1962

15. Wet Electrons - The Radiation Chemistry of Water

A.O. Allen, Chemistry Department

March 14, 1962

16. Fundamental Studies of Radiation Damage in Graphite, BNL 745

Donald G. Schweitzer, Nuclear Engineering Department

April 17, 1962

17. The Role of the Cell Nucleus in Determining Radiosensitivity, BNL 766

Arnold H. Sparrow, Biology Department

May 16, 1962

18. Accelerators of the Future, BNL 741

John P. Blewett, Accelerator Department

June 13,1962

19. The Renewal of Cells and Molecules - The Fountain of Youth Walter L. Hughes, Medical Department

(Continued inside back cover) 